\title{
SHEDDING LIGHT ON DENIGRATION: ITS ETYMOLOGY AND USES
}

\author{
Kaitlin Anne O’Neill
}

Traditionally, black and white symbolism has been operative in many aspects of the Western world. The association of darkness with evil or corruption and of light with purity or goodness is a recurring motif in the Bible as well as countless other pieces of Western literature, art, and more. Recently, I have been curious as to how this dichotomy and its associations are present - if at all - in the English language itself. In an increasingly linguistically conscious world, could language that seems to associate the color black with depravity be construed as racially offensive? One such word that potentially bears these racial implications is denigrate, and I think both its etymology and usage are worth exploring.

Although not necessarily common in quotidian conversation, I have found that the word denigrate does arise in more scholarly writing, primarily with reference to a disparaging remark or action. The word comes from the Latin nigrare, meaning 'to make black'. The prefix de-, although often signifying 'the opposite of', is here used as an intensifier meaning 'down from' or 'down all the way', i.e. 'completely'. Based on a rudimentary knowledge of Latin, I was struck by the root of the word - niger - and the associations of blackness with tainting or degradation. Thus I became interested in exploring the relationship between the literal and figurative darkening implied by denigrate, how the word has evolved semantically in the English language, and how its usage is perceived today.

The Oxford English Dictionary cites the first occurrence of denigrate in the 1526 religious text The Pylgrimage of Perfection. According to the $O E D$, the Bridgettine monk William Bonde uses the word in the phrase "to mynisshe, denygrate, or derke his good name or fame." Unfortunately, no copies of this book were available, and as such the context surrounding the earliest usage of the word is unknown. It seems clear, however, that in this case denigrate denotes the blackening or tainting of one's reputation and "good name."

Another early and significant meaning of "denigrate" arose in The Anatomie of Abuses, written in 1583 by Philip Stubbes ("denigrate," n.d.). Throughout the text, Stubbes warns against a myriad of English practices and customs (even commonly accepted modes of dress or entertainment), which he bitterly denounces as spiritually detrimental. In this particular passage, Stubbes claims that "these...smells...do rather denigrate, darken and obscure the spirit and sences" (p. 78). He is referring specifically to sweet smells of musk and perfume which, though fragrant, in effect debilitate one's senses, thereby corrupting the mind and body. He claims that this pollution compromises one's salvation. Thus, in this context, denigrate connotes a sort of obfuscation or sullying rather than a defamation or disparagement, as in the first usage.

While this word's semantic development is not extremely complicated or lengthy, it is interesting in the sense that the progression violates our expectations. We often think of words as being used initially in a literal sense and then evolving to more nuanced, figurative, or abstract meanings. Denigrate, however, seems to reflect the opposite pattern. According to the $O E D$, the earliest use of the word occurred in a 1526 religious text to signify a sort of moral tainting or degradation, as mentioned above. Similarly, in the 1583 citation, the word denoted a clouding of mental capacities. Interestingly, both instances occur in religious texts. In such texts concerning spirituality, it stands to reason that denigrate might be used more philosophically. It is precisely 
this nonliteral usage, however, that is problematic, as it directly associates blackness with disparagement or degradation. Moreover, the prefix de- can be used to signify a reduction or diminishment, as in "degrade," which could intensify the pejoration of blackness implied by this word.

Later, however, in the early to mid $17^{\text {th }}$ century, it appears that denigrate took on a new, more physical and literal meaning of darkening in hue. For example, a lotion that was believed to blacken gray hair was referred to as "denigrat[ing] the hairs of hoary heads" ("denigrate," n.d.). It is interesting to note that $O E D$ citations of this meaning occur primarily in more technical texts - for example, the Medicinal Dispensatory by Jean de Renou (translated by Richard Tomlinson). It is possible that at this time in London, the beginnings of the scientific revolution led to a bourgeoning interest in medicine and bodily processes, and thus "denigrate" took on a more physical meaning. Furthermore, the introduction of the scientific method could have prompted writers to use language evoking methodical observation of physical processes, which would be more aligned with a literal definition of denigrate. It is perhaps worth noting that according to Google's Ngram Viewer, the use of denigrate peaked during these years.

Interestingly and yet somewhat inexplicably, the word fell out of use in the $18^{\text {th }}$ century. It was, however, revived in $19^{\text {th }}$ century texts in a way that reverted back to its original meaning, as it was again used to signify an attack on character or an attempt to belittle. The writings at this time (such as Morley's Voltaire and Plumptre's Antiquary) are again more philosophical and pertain to politics or devotional literature, which is perhaps why the more figurative sense of the word is employed ("denigrate," n.d.). More recently, in the latter half of the $20^{\text {th }}$ century, denigrate was still used to express a sort of disparagement but in the context of diplomacy and science (perhaps reflecting a more modern, secularized society).

Today, denigrate seems to be most commonly used in reference to a defamation or belittlement of a person or ideology. A Google search quickly relayed news articles in which denigrate was used to reference an attack on someone's character; for example, several journalists noted that athlete Richard Sherman has been called a "thug" for his competitive outbursts, and the writers characterized such accusations as acts of denigration (Zirin, 2014). The word is also employed in a similar way but with regard to ideologies or abstract concepts rather than personal reputations; for example, in one online article, the author warned liberals against denigrating the value of a strong work ethic (Drum, 2014).

Interestingly, then, the meaning of the word has not evolved much from its early $16^{\text {th }}$ century usage; or rather, it has come full circle. What began in the $1500 \mathrm{~s}$ as a term to describe a figurative darkening of one's character or an obscuring of mental capacities evolved into the $17^{\text {th }}$ century meaning of the word, which denoted a literal blackening of a physical body or object. Nearly five hundred years later, however, we have returned almost exclusively to the original use of the word.

Perhaps even more thought provoking than this cyclical pattern of semantic development, however, is the controversial undertones of denigrate and the modern concern surrounding its usage. Etymologically, the Latin root niger (meaning black), is also the root from which racially pejorative and offensive terms such as "nigger" have derived. This commonality between the root of "denigrate" and "nigger" raises interesting questions about our associations of the color black with sullying and degrading forces. As one New York Times journalist writes, "historically black and dark have signified 'bad"" while "white and light have meant 'good'...the question is: Should we now take cognizance of the prejudice inherent in this and try to root it out?" ("On Language," 1990). On one hand, it seems that the literal meaning of denigrate, that is to darken 
in hue, is neutral enough. However, if we consider the semantic development of the word, it becomes clear that denigrate has been firstly and primarily used in the figurative sense, i.e. in a way that equates blackness with a corrupting and tainting force. This language thus treats darkness as inherently bad, undesirable, and devaluing, and as such it seems intuitive that it would be offensive and disparaging to certain racial groups. If words such as denigrate do bear racial implications then, should we make a conscious effort to eliminate them from our linguistic reservoir? Some may argue that repeated usage over time could act as a sort of neutralizer or desensitizer - many individuals who employ the word today may not even be conscious of its etymological connection to blackness and thus have no racial motivations in using it. Furthermore, if we expel words that are entrenched in this dark-light symbolism, are we depleting the rich etymological history of our language? In any case, it seems worthwhile to carefully consider our long-held associations of black and white, and how language informed by these associations may perpetuate racist attitudes. 


\section{REFERENCES}

Denigrate [Def. 1-2]. (n.d.) In Oxford English Dictionary Online, Retrieved February 26, 2014, from

http://www.oed.com/view/Entry/49972?redirectedFrom=denigrate\#eid

Drum, K. (2014, February 11). "We Shouldn't Denigrate the Dignity of Work, Even Accidentally." Retrieved from http://www.motherjones.com/kevin-drum/2014/02/we-shouldnt-denigrate-diginity-workeven-accidentally

(1990, Janurary 28). “On Language; Dark Words of Disapproval.” The New York Times. Retrieved from http://www.nytimes.com/1990/01/28/magazine/on-language-dark-words-ofdisapproval.html

Stubbes, P. (1538). Anatomie of the Abuses in England in Shakespeare's Youth. London: Trubner \& Co.

Zirin, D. (2014, January 20). "Richard Sherman, Racial Coding and Bombastic Brainiacs.” The Nation. Retrieved from http://www.thenation.com/blog/177992/richard-sherman-racial-coding-and-bombasticbrainiacs\# 